ISSN: 1858-4837; E-ISSN: 2598-019X

Volume 17, Nomor 1 (2022),

https://jurnal.uns.ac.id/region

DOI: 10.20961/region.v17i1.44948

\title{
Dominasi kota sebagai konsentrasi fasilitas kesehatan (Studi kasus: Daerah Istimewa Yogyakarta)
}

\author{
Domination of cities as a concentration of health facilities (Case study: Special \\ Region of Yogyakarta)
}

\author{
M I Sadali ${ }^{1}$, M A F Alfana², Z Hadijah'1, E L Rosewidiadari' ${ }^{1}$, dan R Andika1 \\ ${ }^{1}$ Program Studi Pembangunan Wilayah, Fakultas Geografi, Universitas Gadjah Mada \\ ${ }^{2}$ Departemen Geografi Lingkungan, Fakultas Geografi, Universitas Gadjah Mada
}

Corresponding author's email: m.isnaini.s@ugm.ac.id

\begin{abstract}
Abstrak. Penyediaan fasilitas pelayanan kesehatan di suatu wilayah perlu memperhatikan kebutuhan pelayanan, jumlah penduduk, luas wilayah, dan aksesibilitas. Keragaman jumlah dan jenis fasilitas pelayanan yang terdapat di beberapa daerah memungkinkan terjadinya konsentrasi dan pemusatan fasilitas pelayanan pada salah satu daerah. Penelitian ini bertujuan mengidentifikasi dan menganalisis konsentrasi fasilitas pelayanan kesehatan yang berimplikasi pada dominasi kota sebagai pusat pelayanan. Data utama penelitian ini bersumber dari data sekunder dengan metode analisis deskriptif kuantitatif. Penelitian dilaksanakan di Provinsi Daerah Istimewa Yogyakarta dengan unit analisis paling kecil adalah kecamatan. Hasil penelitian menunjukkan bahwa kota masih menjadi wilayah dengan konsentrasi pelayanan kesehatan yang tinggi, dalam hal ini adalah Kota Yogyakarta. Indeks konsentrasi fasilitas kesehatan di Kota Yogyakarta sebesar 10,76, sedangkan indeks terkecil berada di Kabupaten Gunungkidul $(0,51)$. Dominasi kota sebagai pusat pelayanan kesehatan juga diperkuat dengan tingginya indeks konsentrasi fasilitas kesehatan di Kecamatan Umbulharjo $(14,94)$ yang berlokasi di Kota Yogyakarta.
\end{abstract}

Kata Kunci: Ketersediaan; Pengembangan Wilayah; Pusat Pelayanan

Abstract. The provision of health service facilities in an area needs to pay attention to
service needs, population, area size, and accessibility. The diversity of the number and
types of service facilities in several areas allows the concentration and centralization
of service facilities in one area. This study aims to identify and analyze the

Received: October 17, 2020; Accepted: December 18, 2020; Available online: January 31, 2022

Copyright $\odot$ 2022, REGION: Jurnal Pembangunan Wilayah dan Perencanaan Partisipatif 
concentration of health facilities that have implications for the domination of cities as service centers. The source of the main data of this research is from secondary data with quantitative descriptive analysis method. The research was conducted in the Province of Yogyakarta Special Region, with the district as the smallest unit of analysis. The results showed that the city is still an area with a high concentration of health facilities, in this case Yogyakarta City. The concentration index for health facilities in Yogyakarta City was 10.76, while the smallest index was in Gunungkidul Regency (0.51). The dominance of the city as a health service center is also strengthened by the high concentration index of health facilities in Umbulharjo District (14.94) which is located in Yogyakarta City.

Keywords: Availability; Regional Development; Service Center

\section{Pendahuluan}

Pembangunan adalah suatu proses yang dilakukan untuk meningkatkan kesejahteraan masyarakat. Tingkat kesejahteraan pada masyarakat dapat tercapai dengan terpenuhinya kebutuhan pokok pada masyarakat disertai dengan tersedianya fasilitas-fasilitas untuk mendukung pemenuhan kebutuhan tersebut. Ketersediaan fasilitas pelayanan dapat dikaji baik yang menyangkut lokasi maupun kualitas beserta jumlahnya, hal ini sangat erat kaitannya dengan kesejahteraan masyarakat [1]. Ketersediaan dan keterjangkauan akses pada fasilitas pelayanan di suatu tempat sangat penting karena dapat memudahkan masyarakat dalam memenuhi kebutuhan hidup dan menjalankan aktivitas sehari-harinya. Pengetahuan terhadap ketersediaan, kebutuhan, dan aksesibilitas fasilitas pelayanan merupakan konsep penting yang harus dijadikan pedoman bagi perencana dalam merumuskan perencanaan pengembangan wilayah. Salah satu tujuan utama pembangunan (perencanaan fasilitas pelayanan) adalah untuk memenuhi kebutuhan masyarakat, sehingga kesejahteraan masyarakat dapat tercapai [2].

Fasilitas pelayanan secara garis besar dapat diklasifikasikan menjadi fasilitas umum, sosial, dan ekonomi [3]. Contoh pada klasifikasi fasilitas pelayanan sosial yaitu fasilitas kesehatan. Fasilitas kesehatan merupakan salah satu fasilitas dasar yang ketersediaannya sangat penting mengingat kesehatan adalah hak dasar manusia yang perlu dipenuhi [4]. Penyediaan fasilitas kesehatan merupakan tanggung jawab pemerintah pusat dan pemerintah daerah sesuai dengan ketentuan perundang-undangan, yaitu pada Undang-Undang Nomor 36 Tahun 2009 tentang Kesehatan. Berdasarkan ketentuan tersebut dinyatakan bahwa pembangunan nasional harus berlandaskan kesehatan yang memperhatikan kesehatan masyarakat [5]. Pemerintah pusat dan daerah bertanggung jawab atas penyediaan fasilitas kesehatan untuk meningkatkan derajat kesehatan yang setinggi-tingginya. Kesehatan masyarakat merupakan hal yang krusial karena gangguan kesehatan pada masyarakat dapat menimbulkan kerugian ekonomi bagi negara sehingga upaya peningkatan derajat kesehatan merupakan salah satu bentuk investasi pembangunan negara.

Peraturan Pemerintah Nomor 47 Tahun 2016 tentang Fasilitas Pelayanan Kesehatan menyebutkan bahwa penyediaan fasilitas pelayanan kesehatan yang terjangkau bagi seluruh 
lapisan masyarakat perlu diperhatikan dengan menimbang berbagai aspek, seperti kebutuhan pelayanan, jumlah penduduk, luas wilayah, dan aksesibilitas [6]. Prinsip keterjangkauan ini juga selaras dengan Central Place Theory yang memperhatikan jarak (range) dan ambang batas layanan (threshold) yang disampaikan oleh Christaller dalam Muta'ali, Widyanto dan Sadali [7]. Faktanya, bias perencanaan fasilitas pelayanan kesehatan dan fasilitas pelayanan publik secara umum terjadi di Indonesia. Menurut Rodinelli dan Evans dalam Aulia [8] kegiatan produktif, infrastruktur, layanan, dan fasilitas publik umumnya terkonsentrasi di kota. Keberadaan fasilitas pelayanan kesehatan belum terkontrol secara optimal, hal ini dapat dilihat pada konsentrasi fasilitas kesehatan pada wilayah tertentu. Jumlah fasilitas kesehatan di wilayah perkotaan cenderung lebih banyak dan lengkap dibandingkan dengan jumlah fasilitas kesehatan yang ada di perdesaan [9]. Kontrol izin terhadap jumlah fasilitas kesehatan masyarakat, terutama yang dimiliki oleh pihak swasta (non pemerintah) berkembang tidak teratur dengan orientasi yang berbeda (bisnis/keuntungan). Kondisi yang terjadi di lapangan, fasilitas kesehatan yang dimiliki dan dikembangkan oleh swasta banyak terdapat di perkotaan, sehingga menambah terkonsentrasinya fasilitas kesehatan di kota. Jumlah penduduk di kota lebih banyak yang dilayani daripada penduduk di desa, dan lebih menjanjikan dari segi bisnis atau keuntungan perusahaan [10].

Berdasarkan Peraturan Pemerintah Republik Indonesia Nomor 47 Tahun 2016 tentang Fasilitas Pelayanan Kesehatan, dalam Pasal 11 "Pemerintah Daerah kabupaten/kota wajib menyediakan paling sedikit 1 (satu) pusat kesehatan masyarakat pada setiap kecamatan". Meskipun demikian, pusat kesehatan masyarakat (puskesmas) dapat lebih dari 1 (satu) pada tiap kecamatan dengan mempertimbangkan kebutuhan pelayanan, jumlah penduduk, dan aksesibilitas. Rasio ideal puskesmas terhadap kecamatan (yaitu minimal 1 puskesmas di 1 kecamatan) sudah tercapai di Provinsi DIY, dengan besar rasio 1,55 [11]. Hal ini berarti bahwa setiap kecamatan di Provinsi DIY terdapat 1-2 puskesmas. Sebaran fasilitas kesehatan di Provinsi Daerah Istimewa Yogyakarta (DIY) dapat dikatakan relatif merata di setiap kabupaten/kota. Permasalahan lain yang muncul pada tahun 2014 adalah masih terdapat desa/kelurahan di D.I. Yogyakarta yang kesulitan mengakses fasilitas pelayanan kesehatan. Sebanyak 187 desa/kelurahan atau 42,69\% masih mengalami kesulitan mengakses rumah sakit karena memiliki jarak lebih dari $6 \mathrm{~km}, 45$ desa/kelurahan atau 10,27\% masih kesulitan mengakses tempat praktek dokter, dan 5 desa/kelurahan masih sulit mengakses Puskesmas pembantu [12].

Kota Yogyakarta sebagai ibukota Provinsi DIY tidak hanya bersifat administrasi, gejala primacy atau pemusatan perkembangan wilayah terjadi di Kota Yogyakarta dan sekitarnya [13]. Fenomena ini menunjukkan bahwa telah terjadi pemusatan sistem pusat pelayanan wilayah dan terjadi konsentrasi fasilitas pelayanan di Kota Yogyakarta [14]. Penelitian ini berusaha menganalisis dominasi kota sebagai pusat konsentrasi fasilitas pelayanan kesehatan melalui tujuan penelitian untuk mengidentifikasi ketersediaan fasilitas kesehatan dan menganalisis tingkat konsentrasi fasilitas kesehatan di daerah penelitian. 


\section{Metode}

Metode penelitian kuantitatif yang digunakan dalam penelitian ini memanfaatkan data sekunder sebagai sumber utama untuk olah data dan analisis. Penelitian ini menggunakan analisis deskriptif dengan lokasi penelitian secara administratif dilaksanakan di Provinsi Daerah Istimewa Yogyakarta (DIY). Provinsi DIY terbagi atas 5 (lima) kabupaten/kota, yaitu: Kabupaten Bantul, Kabupaten Kulon Progo, Kabupaten Gunungkidul, Kabupaten Sleman, dan Kota Yogyakarta. Adapun jumlah kecamatan di Provinsi DIY berjumlah 78 kecamatan. Peta daerah penelitian dapat dilihat pada Gambar 1.

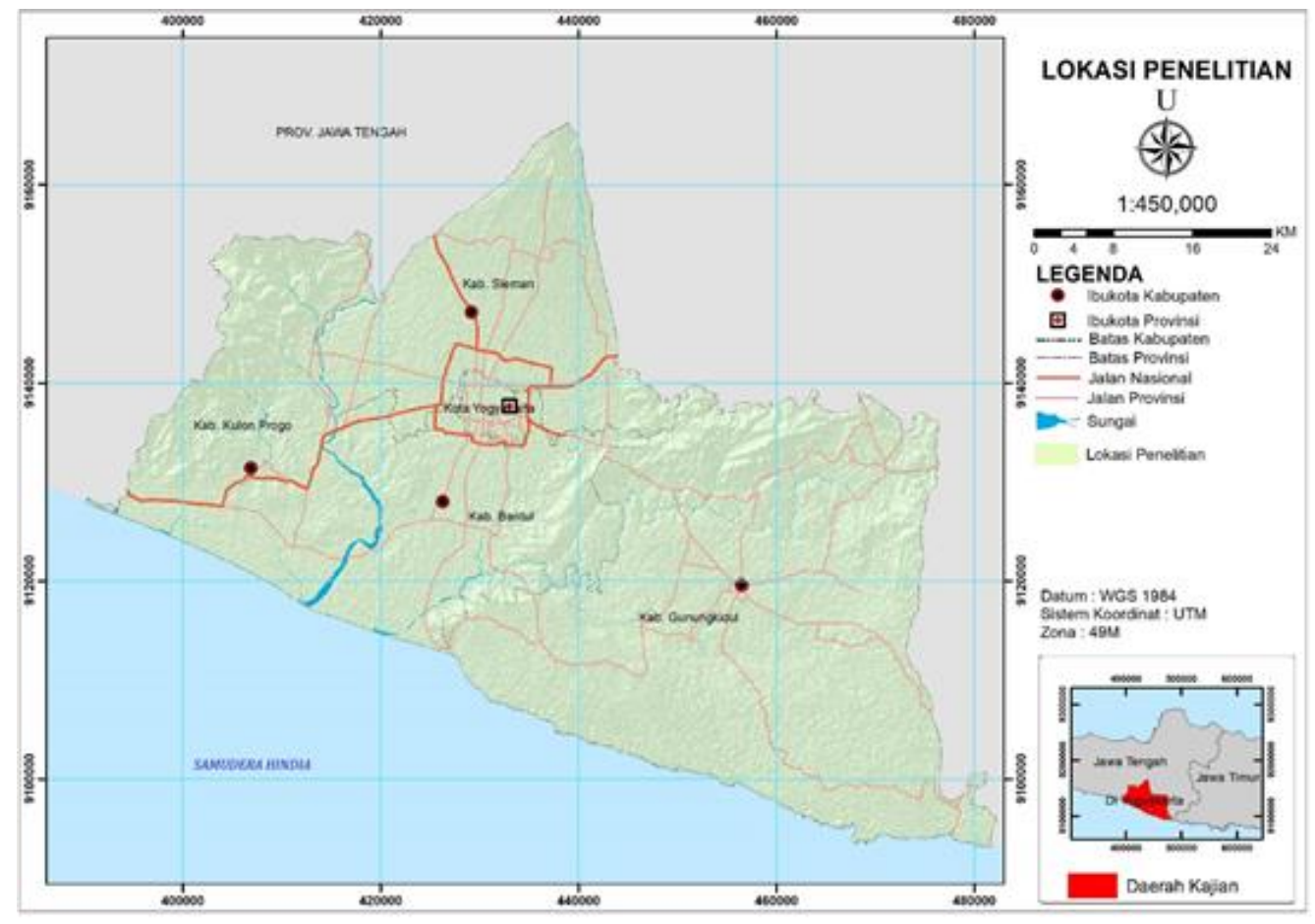

Gambar 1. Peta administrasi Provinsi Daerah Istimewa Yogyakarta.

Perhitungan indeks konsentrasi menurut lingkup wilayah dibagi menjadi 2 (dua), pada tingkat kabupaten/kota unit analisis terkecil analisis adalah kecamatan dan pada tingkat provinsi unit analisis terkecil analisis adalah kabupaten/kota. Beberapa sumber data utama dalam penelitian ini dapat dilihat pada Tabel 1 berikut ini.

Tabel 1. Data utama penelitian dan sumber data penelitian.

\begin{tabular}{cll}
\hline No & \multicolumn{1}{c}{ Data } & \multicolumn{1}{c}{ Sumber } \\
\hline 1 & Jumlah penduduk & Kabupaten dalam angka \\
2 & Jumlah fasilitas pelayanan & Kabupaten dalam angka, Profil Kesehatan Provinsi DIY \\
& kesehatan & \\
3 & Jenis fasilitas pelayanan kesehatan & Kabupaten dalam angka, Profil Kesehatan Provinsi DIY \\
4 & Luas wilayah & BPS \\
5 & Bobot jenis fasilitas & Peraturan Menteri PU No. 41/PRT/M/2007 dan SNI 03- \\
& & $1733-2004$ \\
\hline
\end{tabular}


Untuk mengetahui tingkat konsentrasi dari fasilitas pelayanan kesehatan di daerah penelitian, digunakan rumus hasil modifikasi indeks konsentrasi.

Formula indeks konsentrasi [7].

$$
\mathrm{IK}=\frac{\% \mathrm{Fi}}{\% \mathrm{TFi}}
$$

Modifikasi formula indeks konsentrasi dengan memperhatikan bobot fasilitas kesehatan.

$$
\mathrm{IK}=\frac{\mathrm{Fi} \times \mathrm{C}}{\mathrm{TFi} \times \mathrm{C}} \times 100
$$

Modifikasi formula indeks konsentrasi dengan memperhatikan bobot fasilitas kesehatan dan luas wilayah.

$$
\mathrm{IK}=\frac{\% \mathrm{Fi} \times \mathrm{C}}{\% \mathrm{Li} \times \mathrm{C}}
$$

\section{Keterangan:}

IK = indeks konsentrasi fasilitas

$\mathrm{Fi} \quad=$ jumlah unit fasilitas pada sub wilayah $\mathrm{i}$

$\mathrm{TFi} \quad=$ total jumlah unit fasilitas pada wilayah $\mathrm{i}$

$\mathrm{Li} \quad=$ luas wilayah $\mathrm{i}$

$\mathrm{C} \quad=$ bobot jenis fasilitas (lihat Tabel 2)

Tabel 2. Penentuan bobot jenis yang mengacu pada SNI 03-1733-2004.

\begin{tabular}{lcc}
\hline \multicolumn{1}{c}{ Jenis Fasilitas Kesehatan } & Penduduk yang Dilayani & Bobot Jenis \\
\hline Rumah sakit & 240.000 & 4 \\
RS bersalin & 30.000 & 2 \\
Poliklinik/balai pengobatan lingkungan & 30.000 & 2 \\
Puskesmas & 120.000 & 3 \\
Puskesmas pembantu & 30.000 & 2 \\
Apotek & 30.000 & 2 \\
Posyandu & 1.250 & 1 \\
\hline
\end{tabular}

\section{Hasil penelitian dan pembahasan}

\subsection{Identifikasi fasilitas pelayanan kesehatan}

Fasilitas pelayanan kesehatan dasar di Provinsi DIY dilaksanakan oleh Puskesmas, klinik pratama, praktik dokter/dokter gigi perseorangan, sedangkan pelayanan kesehatan rujukan dilaksanakan oleh rumah sakit umum dan rumah sakit khusus [15]. Analisis difokuskan pada rumah sakit dan puskesmas sebagai representatif dari fasilitas pelayanan kesehatan dasar dan fasilitas pelayanan kesehatan rujukan atau lanjut. Pada tahun 2014 jumlah keseluruhan fasilitas pelayanan kesehatan di Provinsi DIY berjumlah 6.712 unit (lihat Tabel 3) dan pada tahun 2019 bertambah menjadi 6.787 unit. Kondisi eksisting pada tahun 2019 fasilitas 
kesehatan yang ada di Provinsi DIY adalah rumah sakit berjumlah 48 unit, rumah sakit bersalin 45 unit, poliklinik/ balai pengobatan lingkungan 146 unit, puskesmas 167 unit, puskesmas pembantu 295 unit, apotek 359 unit, dan posyandu 5.727 unit (lihat Tabel 4).

Berdasarkan Peraturan Menteri Kesehatan Nomor 75 Tahun 2014 tentang Puskesmas, setiap puskesmas di Indonesia pada tahun 2019 ditargetkan dapat memberikan pelayanan sesuai standar. Puskesmas di Provinsi DIY yang memberikan pelayanan sesuai standar baru mencapai $91,74 \%$, angka ini tergolong tinggi dibandingkan dengan provinsi lain di Indonesia [16]. Meskipun demikian masih diperlukan peningkatan pelayanan kesehatan yang ditinjau dari fasilitas kesehatan, SDM kesehatan, pembiayaan kesehatan dan pengendalian penyakit. Menurut data profil kesehatan Provinsi DIY, dari total persebaran puskesmas yang ada belum seluruh puskesmas terakreditasi. Dinas Kesehatan Provinsi DIY melakukan beberapa upaya kesehatan dengan melaksanakan tugas dan fungsinya yang salah satunya adalah memastikan ketersediaan fasilitas pelayanan kesehatan dasar dan rujukan.

Tabel 3. Jumlah dan distribusi fasilitas kesehatan di Provinsi DIY Tahun 2014 [17-21].

\begin{tabular}{lrrrrrrr}
\hline $\begin{array}{c}\text { Kabupaten/ } \\
\text { Kota }\end{array}$ & $\begin{array}{c}\text { Rumah } \\
\text { Sakit }\end{array}$ & $\begin{array}{c}\text { RS } \\
\text { Bersalin }\end{array}$ & Poliklinik & Puskesmas & $\begin{array}{c}\text { Puskesmas } \\
\text { Pembantu }\end{array}$ & $\begin{array}{c}\text { Apotek/ } \\
\text { Pharmacy }\end{array}$ & $\begin{array}{c}\text { Posyan- } \\
\text { du }\end{array}$ \\
\hline Bantul & 13 & 14 & 45 & 27 & 59 & 47 & 1.132 \\
Gunungkidul & 5 & 3 & 42 & 30 & 112 & 19 & 1.466 \\
Kota & 12 & 18 & 18 & 16 & 9 & 39 & 625 \\
Yogyakarta & & & & & & & \\
Kulon Progo & 5 & 8 & 10 & 21 & 59 & 13 & 913 \\
Sleman & 6 & 53 & 26 & 69 & 46 & 195 & 1.537 \\
Provinsi DIY & 41 & 96 & 141 & 163 & 285 & 313 & 5.673 \\
\hline
\end{tabular}

Tabel 4. Jumlah dan distribusi fasilitas kesehatan di Provinsi DIY Tahun 2019 [22-26].

\begin{tabular}{lrrrrrrr}
\hline $\begin{array}{c}\text { Kabupaten/ } \\
\text { Kota }\end{array}$ & $\begin{array}{c}\text { Rumah } \\
\text { Sakit }\end{array}$ & $\begin{array}{c}\text { RS } \\
\text { Bersalin }\end{array}$ & Poliklinik & Puskesmas & $\begin{array}{c}\text { Puskesmas } \\
\text { Pembantu }\end{array}$ & $\begin{array}{c}\text { Apotek/ } \\
\text { Pharmacy }\end{array}$ & $\begin{array}{c}\text { Posyan- } \\
\text { du }\end{array}$ \\
\hline Bantul & 16 & 8 & 44 & 29 & 58 & 58 & 1.141 \\
Gunungkidul & 6 & 1 & 41 & 33 & 110 & 30 & 1.431 \\
Kota & 13 & 12 & 22 & 16 & 8 & 42 & 622 \\
Yogyakarta & & & & & & & \\
Kulon Progo & 6 & 0 & 12 & 21 & 58 & 27 & 960 \\
Sleman & 7 & 24 & 27 & 68 & 61 & 202 & 1.573 \\
Provinsi DIY & 48 & 45 & 146 & 167 & 295 & 359 & 5.727 \\
\hline
\end{tabular}

Tingkat ketersediaan fasilitas pelayanan dapat diketahui dengan mengidentifikasi jumlah unit dan jenis pelayanan yang tersedia. Jumlah tersebut dapat mengindikasikan perkembangan wilayah beserta fungsi pelayanan wilayah berdasarkan daya layan. Ketersediaan fasilitas pelayanan pada lingkup wilayah tertentu dapat mencerminkan keberlangsungan fungsi pelayanan sesuai kebutuhan per wilayah dengan mempertimbangkan banyaknya penduduk dan cakupan wilayah (skala pelayanan) yang dilayani. Kebutuhan fasilitas pelayanan wilayah 
akan meningkat seiring meningkatnya penduduk di suatu wilayah [27]. Salah satu aspek yang dapat meningkatkan kesejahteraan penduduk yaitu dengan terpenuhinya kebutuhan fasilitas pelayanan sesuai dengan porsi tiap wilayah. Fasilitas pelayanan kesehatan dasar dan rujukan di Provinsi DIY mengalami penambahan pada periode lima tahun terakhir (tahun 2014-2019) dengan variasi jumlah penambahan berbeda-beda pada jenisnya. Penurunan fasilitas kesehatan hanya terjadi pada rumah sakit bersalin. Secara keseluruhan total penambahan jumlah fasilitas kesehatan dasar maupun lanjut (rujukan) di Provinsi DIY berjumlah 75 unit.

Fasilitas pelayanan kesehatan rujukan berupa rumah sakit mengalami penambahan pada kurun waktu 2014-2019, yaitu sebesar 7 unit, dari 41 rumah sakit menjadi 48 rumah sakit. Rumah sakit bersalin justru mengalami penurunan yang signifikan sebesar 51 unit, sehingga pada tahun 2019 jumlah rumah sakit bersalin menjadi 45 unit. Penurunan jumlah rumah sakit bersalin di Provinsi DIY terjadi karena beberapa berubah status jenis fasilitas kesehatannya atau sudah tidak beroperasional lagi. Fasilitas pelayanan kesehatan dasar di Provinsi DIY berupa puskesmas juga mengalami penambahan 4 unit pada 5 tahun terakhir, pada tahun 2014 Provinsi DIY memiliki 163 puskesmas sedangkan pada tahun 2019 bertambah menjadi 167 puskesmas. Meskipun penambahan puskesmas ini paling sedikit dibandingkan dengan fasilitas kesehatan yang lain di Provinsi DIY, akan tetapi secara nasional jumlah ini relatif cukup besar karena penambahan rata-rata puskesmas di Indonesia dalam 5 tahun sebesar 2 puskesmas per provinsi [11].

Perencanaan pembangunan membutuhkan suatu pegangan atau pedoman sebelum melakukan aksi pembangunan. Konsep Pedoman Perencanaan Lingkungan Permukiman Kota Departemen Pekerjaan Umum 1979 dan Standar Nasional Indonesia tentang Tata Cara Perencanaan Lingkungan Perumahan di Perkotaan Tahun 2014 merupakan dokumen nasional yang berisikan pedoman atau sebagai acuan dalam perencanaan. Berdasarkan pedoman tersebut dapat disusun rencana lebih mendetail untuk bahan perencanaan fasilitas pelayanan umum di daerah. Dengan diketahuinya Standar Pelayanan Minimal (SPM) pada masing-masing tingkat fasilitas kesehatan tertentu, maka akan dapat dilakukan analisis mengenai tingkat terpenuhinya daya layan atau efektifitas daya layan tiap fasilitas kesehatan. Jumlah fasilitas kesehatan ideal dapat diketahui dengan melakukan perbandingan antara jumlah fasilitas kesehatan dan total penduduk yang dilayani. Kebutuhan fasilitas pelayanan kesehatan di Provinsi DIY menurut jumlah penduduk yang dilayani secara umum sudah terpenuhi, baik fasilitas pelayanan kesehatan dasar maupun lanjut/rujukan. Hanya saja fasilitas pelayanan kesehatan rujukan (rumah sakit) belum tersebar secara merata, sebagai contoh di Kabupaten Sleman terdapat 7 rumah sakit yang mengelompok di 2 kecamatan, yaitu 4 rumah sakit di Kecamatan Gamping dan 3 rumah sakit di Kecamatan Mlati. Keberadaan fasilitas pelayanan kesehatan yang memadai dan sesuai banyaknya penduduk yang dilayani pada suatu wilayah perlu diperhatikan. Selain itu, penempatan fasilitas kesehatan yang tepat juga diperlukan dengan mempertimbangkan luas wilayah di suatu tempat. Wilayah dengan luasan yang besar sebaiknya memiliki fasilitas-fasilitas yang penempatannya strategis, sehingga aksesibilitas dan daya jangkau menuju fasilitas tersebut mudah digapai masyarakat setempat. Penelitian 
sebelumnya yang relevan juga mengkaji efektivitas pusat pelayanan wilayah dapat diukur melalui efisiensi dan keterjangkauan fasilitas pelayanan [28].

Ulman dalam Aulia menyampaikan bahwa pada proses pemenuhan kebutuhan tiap wilayah diperlukan keterkaitan antar wilayah, yaitu tiap-tiap wilayah dengan fungsi pelayanan yang berbeda diharapkan dapat saling memenuhi kebutuhan penduduk terhadap fasilitas pelayanan tertentu [8]. Fasilitas pelayanan wilayah dengan daya layan yang lebih luas dapat melayani kebutuhan penduduk di wilayahnya sendiri dan di luar wilayahnya. Dengan demikian prinsip daya layan dari fasilitas pelayanan kesehatan di Indonesia didasarkan pada pemenuhan kebutuhan penduduk menurut jumlah penduduk (threshold) dan ketersediaan pada masingmasing wilayah administrasi (range). Prinsip tersebut juga sesuai dengan Central Place Theory yang memperhatikan ambang batas minimal sebuah fasilitas pelayanan wilayah agar dapat berlangsung dan optimal memenuhi kebutuhan penduduk (threshold) serta jangkauan (jarak) maksimum sebuah fasilitas pelayanan wilayah mampu melayani penduduk (range) [7].

\subsection{Konsentrasi fasilitas pelayanan kesehatan}

Ketersediaan fasilitas pelayanan kesehatan di Provinsi DIY dapat diidentifikasi menurut kuantitas (jumlah) dan jenisnya, sehingga dalam merumuskan formula untuk mengukur tingkat konsentrasi fasilitas pelayanan kesehatan mempertimbangkan pembobotan. Hal ini berkaitan dengan penjenjangan dari masing-masing jenis fasilitas kesehatan yang memiliki daya layan berbeda-beda menurut fungsinya. Analisis konsentrasi fasilitas pelayanan kesehatan di Provinsi DIY dapat diidentifikasi dengan mengolah data jumlah fasilitas kesehatan tiap kecamatan beserta data luas wilayah dan jumlah penduduk pada tahun 2014 dan 2018. Analisis pada 2 (dua) tahun yang berbeda dilakukan untuk melihat perubahan serta perkembangan tingkat konsentrasi pelayanan kesehatan di daerah yang sama. Fasilitas pelayanan kesehatan di Provinsi DIY yang akan dijadikan indikator jenis meliputi rumah sakit, rumah sakit bersalin, poliklinik/balai pengobatan lingkungan, puskesmas, puskesmas pembantu, apotek (pharmacy), dan posyandu.

Indeks konsentrasi fasilitas pelayanan digunakan sebagai salah satu cara untuk mengidentifikasi ketersediaan dan pemusatan fasilitas. Artinya, adanya indeks konsentrasi fasilitas pelayanan ini menunjukkan seberapa besar suatu wilayah dapat berfungsi sebagai pusat pelayanan untuk wilayah itu sendiri maupun wilayah di sekitarnya. Metode indeks konsentrasi fasilitas pelayanan yang digunakan merupakan hasil perbandingan antara jumlah unit fasilitas kesehatan sesuai dengan jenisnya di wilayah administrasi dengan variabel pembanding berupa luas wilayah. Perbandingan tersebut dilakukan untuk melihat proporsi suatu nilai jumlah unit terhadap proporsi nilai lainnya yaitu luas wilayah. Setiap nilai indeks konsentrasi fasilitas pelayanan kesehatan dapat mengindikasikan seberapa besar dominasi wilayah terhadap keseluruhan wilayah sebagai penyedia pelayanan kesehatan. Semakin besar indeks konsentrasi fasilitas pelayanan, maka akan semakin banyak peran suatu wilayah dalam mengalokasikan wilayahnya untuk berfungsi sebagai pusat pelayanan. Tingginya angka fungsi pelayanan menunjukkan semakin besar fungsi pelayanan yang digapai masyarakat di tiap 
kecamatan sehingga masyarakat lebih mudah memperoleh pelayanan kesehatan dilihat dari orientasi geografis penduduk.

Persebaran tenaga medis dan fasilitas penunjang kesehatan seperti puskesmas dan rumah sakit saat ini masih menumpuk di kota [9]. Fasilitas pelayanan publik yang tidak memadai dan memiliki kualitas kurang memuaskan akan memicu mobilitas penduduk yang lebih tinggi [29]. Pemerintah Provinsi DIY telah berupaya mendorong penguatan pelayanan kesehatan dengan menyediakan fasilitas pelayanan kesehatan yang tersebar di 4 kabupaten dan 1 kota. Meskipun demikian, di Provinsi DIY masih terdapat pemusatan fasilitas kesehatan di beberapa wilayah. Perhitungan indeks konsentrasi berdasarkan cakupan wilayahnya dibagi menjadi 2 (dua), yaitu pada wilayah administrasi kabupaten/kota dan provinsi. Pada tingkat kabupaten/kota, indeks konsentrasi terendah tahun 2014 berada pada Kecamatan Purwosari (Kabupaten Gunungkidul) atau sebesar 2,18 sedangkan indeks konsentrasi tertinggi tahun 2014 ada pada Kecamatan Umbulharjo di Kota Yogyakarta atau sebesar 15,07. Tahun 2019, indeks konsentrasi terendah dan tertinggi menurut tingkat kabupaten/kota masih berada pada kecamatan yang sama namun dengan angka yang berbeda, yaitu terendah di Kecamatan Purwosari dengan angka 2,35 dan tertinggi di Kecamatan Umbulharjo dengan angka 14,94.

Kecamatan Purwosari menduduki peringkat paling rendah dalam indeks konsentrasi pelayanan fasilitas kesehatannya, hal ini menunjukkan bahwa ketersediaan dan daya layan fasilitas kesehatan masih tergolong rendah. Kelengkapan fasilitas pelayanan merupakan salah satu indikator perkembangan wilayah, selain itu kondisi sosial ekonomi masyarakat juga dapat menjadi simpulan awal kesuksesan pembangunan wilayah. Penelitian yang dilakukan Kodoatie dalam Hariyani, Usman dan Kurniawan [30] juga menunjukkan bahwa rendahnya ketersediaan fasilitas dan kualitas infrastruktur pada suatu wilayah berbanding lurus dengan tingkat perekonomiannya. Kebanyakan masyarakat di Kecamatan Purwosari hidup dari lahan pertanian, yaitu padi dan singkong. Kondisi geografis di Kecamatan Purwosari juga memiliki karakter topografi yang bervariasi, dari yang landai-hingga terjal dan termasuk dalam jajaran perbukitan karst atau sering disebut Pegunungan Sewu [31]. Pola bertahan hidup masyarakat ini masih menggambarkan karakteristik hidup tradisional dengan mengandalkan sektor pertanian (agraris) sebagai mata pencaharian utama. Kecamatan Purwosari terdiri dari beberapa dusun yang terdiri dari kelompok-kelompok permukiman dengan jarak antar dusun yang cukup jauh. Kecamatan Purwosari memiliki jumlah penduduk paling rendah di Kabupaten Gunungkidul, yaitu 21.107 jiwa pada tahun 2019. Kondisi Kecamatan Purwosari yang demikian menyebabkan sedikitnya fasilitas kesehatan yang dibangun di daerah tersebut. Tercatat pada tahun 2019 di Kecamatan Purwosari tidak ada fasilitas rumah sakit, rumah sakit bersalin, dan poliklinik di wilayah ini. Fasilitas kesehatan lainnya yang terdapat di sana adalah 1 puskesmas, 4 puskesmas pembantu, 1 apotek, dan 32 posyandu.

Kondisi yang sebaliknya terjadi di Kecamatan Umbulharjo yang memiliki indeks konsentrasi pelayanan fasilitas kesehatan tertinggi di Provinsi DIY. Kondisi eksisting pada tahun 2019 fasilitas pelayanan kesehatan di Kecamatan Umbulharjo memiliki jumlah dan kelengkapan fasilitas kesehatan yang sangat memadai, yaitu: 3 rumah sakit, 1 rumah sakit bersalin, 4 
poliklinik, 1 puskesmas, 2 puskesmas pembantu, 6 apotek, dan 92 posyandu. Hal ini menunjukkan bahwa indeks konsentrasi merepresentasikan kelengkapan fasilitas kesehatan dan daya layan optimal dari fasilitas kesehatan dalam memenuhi kebutuhan penduduk terutama di Kecamatan Umbulharjo. Lokasi relatif Kecamatan Umbulharjo berada di pinggiran Kota Yogyakarta dengan akses yang baik menuju pusat kota dan daerah sekitarnya, hal ini menyebabkan pertumbuhan fasilitas pelayanan juga pesat di kecamatan ini. Kondisi topografi di wilayah ini mendukung adanya ketersediaan fasilitas yang lengkap. Kecamatan ini dapat dikategorikan sebagai pusat pertumbuhan dari kecamatan-kecamatan di sekitarnya.

Hasil komparasi fungsi pelayanan tahun 2014 dan 2019 menurut tingkat kabupaten/kota di Provinsi DIY menunjukkan bahwa ada kecamatan yang mengalami peningkatan indeks konsentrasi fasilitas kesehatan dan ada yang mengalami penurunan, serta ada pula kecamatan dengan perkembangan indeks konsentrasi fasilitas kesehatan yang stagnan selama 5 tahun tersebut. Peningkatan indeks konsentrasi fasilitas kesehatan didominasi di Kota Yogyakarta, yaitu sebanyak 5 (lima) kecamatan mengalami peningkatan. Kelima kecamatan tersebut adalah Kecamatan Kraton, Gondomanan, Ngampilan, Gedongtengen, dan Tegalrejo. Hal ini menunjukkan adanya perkembangan (penambahan) fasilitas kesehatan di Kota Yogyakarta secara umum. Peningkatan terbesar dalam kurun 5 tahun terjadi di Kecamatan Ngampilan Kota Yogyakarta. Hal ini terjadi karena penduduk Kecamatan Ngampilan mengalami peningkatan yang besar diikuti dengan penambahan fasilitas kesehatan, berupa 1 poliklinik dan 1 apotek. Kondisi tersebut tepat dikarenakan seiring meningkatnya penduduk, fasilitas yang dibutuhkan juga meningkat. Kenaikan jumlah penduduk seharusnya diikuti dengan penambahan fasilitas pendukung mengingat ketersediaan tersebut menentukan tingkat perkembangan wilayah [30]. Penurunan indeks konsentrasi fasilitas kesehatan terendah berada di kecamatan yang memiliki penduduk terendah di Provinsi DIY, yaitu Kecamatan Pakualaman di Kota Yogyakarta. Kecamatan Pakualaman memiliki luas wilayah terkecil di Provinsi DIY, yaitu sekitar 63 hektar. Akan tetapi, Kecamatan Pakualaman terletak di tengah kota dan berbatasan dengan kecamatan-kecamatan yang berpengaruh, yaitu sebelah utara berbatasan dengan Kecamatan Danurejan, sebelah selatan berbatasan dengan Kecamatan Mergangsan, sebelah barat berbatasan dengan Kecamatan Gondomanan, dan sebelah timur berbatasan dengan Kecamatan Umbulharjo. Atas keuntungan letak geografis itu Kecamatan Pakualaman yang memiliki indeks konsentrasi cukup rendah tidak begitu menjadi masalah bagi masyarakat di kecamatan ini karena kemudahan akses terhadap fasilitas kesehatan ke kecamatan lain.

Berdasarkan komparasi nilai indeks konsentrasi fasilitas pelayanan kesehatan tingkat provinsi di tahun 2014 dan 2019, tercatat adanya perubahan nilai indeks konsentrasi yang tidak terlalu signifikan di tiap kabupaten/kota. Pada tahun 2014, Kota Yogyakarta berada pada klasifikasi tertinggi (I) dengan nilai indeks konsentrasi fasilitas pelayanan kesehatan sebesar 10,9. Kabupaten dengan nilai indeks konsentrasi klasifikasi sedang (II) ada pada 2 (dua) kabupaten, yaitu Kabupaten Sleman dengan nilai indeks konsentrasi sebesar 1,67 dan Kabupaten Bantul dengan nilai indeks konsentrasi 1,25. Klasifikasi terendah (III) ditempati oleh Kabupaten Kulon Progo dengan nilai indeks konsentrasi 0,80 dan Kabupaten Gunungkidul dengan nilai indeks 
konsentrasi 0,52 (lihat Tabel 5). Pada tahun 2018, terdapat perubahan angka nilai indeks konsentrasi fasilitas pelayanan kesehatan di semua kabupaten/kota namun tidak signifikan. Beberapa kabupaten/kota yang mengalami peningkatan indeks konsentrasi selama 5 tahun tersebut yaitu Kabupaten Bantul yang naik menjadi 1,26 dan Kabupaten Kulon Progo sebesar 0,83 . Adapun Kabupaten Sleman, Kabupaten Gunungkidul dan Kota Yogyakarta mengalami penurunan nilai indeks konsentrasi walaupun tidak signifikan. Kabupaten Sleman mengalami penurunan menjadi 1,66, sedangkan Kabupaten Gunungkidul mengalami penurunan menjadi 0,51 dan Kota Yogyakarta mengalami penurunan menjadi 10,76 (lihat Tabel 6).

Hasil klasifikasi menurut tingkat konsentrasi di provinsi DIY pada tahun 2014 dan 2019 menunjukkan bahwa klasifikasi tertinggi ditempati oleh Kota Yogyakarta. Kota Yogyakarta merupakan satu-satunya daerah berstatus kota dengan 4 (empat) lainnya berstatus kabupaten. Luas wilayah Kota Yogyakarta paling sempit dibandingkan wilayah kabupaten lainnya, yaitu hanya 3.250 hektar. Akan tetapi, kepadatan penduduk Kota Yogyakarta menempati angka tertinggi dari kabupaten lainnya, yaitu mencapai 13.154 jiwa per kilometer persegi. Terdapat korelasi kepadatan penduduk yang berdampak signifikan terhadap perkembangan fasilitas di suatu wilayah, yaitu semakin tinggi tingkat kepadatan penduduk, maka semakin banyak ketersediaannya [32]. Tingginya kepadatan penduduk di Kota Yogyakarta dikarenakan Kota Yogyakarta berkedudukan sebagai ibu kota Provinsi DIY, hal tersebut menjadi faktor pendukung utama Kota Yogyakarta menduduki klasifikasi tertinggi. Status ibu kota yang melekat pada Kota Yogyakarta menyebabkan banyaknya aktivitas masyarakat sehingga kebutuhan fasilitas pelayanan juga semakin meningkat dan bervariasi. Lokasi fasilitas kesehatan melibatkan komitmen alokasi sumber daya untuk rencana jangka panjang. Keputusan lokasi fasilitas kesehatan yang terencana dengan baik akan sangat menunjang pemenuhan kebutuhan untuk wilayah itu sendiri maupun wilayah lain.

Tabel 5. Tingkat konsentrasi fasilitas pelayanan kesehatan di Provinsi DIY berdasarkan data tahun 2014.

\begin{tabular}{llccccc}
\hline No & Kabupaten/Kota & $\begin{array}{c}\text { Jumlah } \\
\text { Penduduk }\end{array}$ & $\begin{array}{c}\text { Persentase Jumlah } \\
\text { Unit dengan Bobot }\end{array}$ & $\begin{array}{c}\text { Persentase } \\
\text { Luas }\end{array}$ & $\begin{array}{c}\text { Indeks } \\
\text { Konsentrasi }\end{array}$ & $\begin{array}{c}\text { Tingkat } \\
\text { Konsentrasi }\end{array}$ \\
\hline 1 & Bantul & 968.632 & 19,95 & 15,91 & 1,25 & II \\
2 & Kulon Progo & 405.222 & 14,71 & 18,40 & 0,80 & III \\
3 & Gunungkidul & 698.825 & 24,11 & 46,62 & 0,52 & III \\
4 & Sleman & 1.163 .970 & 30,12 & 18,04 & 1,67 & II \\
5 & Kota Yogyakarta & 400.467 & 11,12 & 1,02 & 10,90 & I \\
\hline
\end{tabular}

Tabel 6. Tingkat konsentrasi fasilitas pelayanan kesehatan di Provinsi DIY berdasarkan data tahun 2018.

\begin{tabular}{clccccc}
\hline No & Kabupaten/Kota & $\begin{array}{c}\text { Jumlah } \\
\text { Penduduk }\end{array}$ & $\begin{array}{c}\text { Persentase Jumlah } \\
\text { Unit dengan Bobot }\end{array}$ & $\begin{array}{c}\text { Persentase } \\
\text { Luas }\end{array}$ & $\begin{array}{c}\text { Indeks } \\
\text { Konsentrasi }\end{array}$ & $\begin{array}{c}\text { Tingkat } \\
\text { Konsentrasi }\end{array}$ \\
\hline 1 & Bantul & 1.006 .692 & 20,07 & 15,91 & 1,26 & II \\
2 & Kulon Progo & 425.758 & 15,30 & 18,40 & 0,83 & II \\
\hline
\end{tabular}




\begin{tabular}{clccccc}
\hline No & Kabupaten/Kota & $\begin{array}{c}\text { Jumlah } \\
\text { Penduduk }\end{array}$ & $\begin{array}{c}\text { Persentase Jumlah } \\
\text { Unit dengan Bobot }\end{array}$ & $\begin{array}{c}\text { Persentase } \\
\text { Luas }\end{array}$ & $\begin{array}{c}\text { Indeks } \\
\text { Konsentrasi }\end{array}$ & $\begin{array}{c}\text { Tingkat } \\
\text { Konsentrasi }\end{array}$ \\
\hline 3 & Gunungkidul & 736.210 & 23,65 & 46,62 & 0,51 & III \\
4 & Sleman & 1.206 .714 & 30,00 & 18,04 & 1,66 & II \\
5 & Kota Yogyakarta & 427.528 & 10,97 & 1,02 & 10,76 & I \\
\hline
\end{tabular}

Pergeseran tingkat konsentrasi fasilitas kesehatan Provinsi DIY terjadi di Kabupaten Kulon Progo yang sebelumnya berada pada tingkat tiga (III) naik menjadi tingkat dua (II). Naiknya tingkat konsentrasi berbanding lurus dengan naiknya indeks konsentrasi fasilitas kesehatan di Kabupaten Kulon Progo. Selain itu, tingkat konsentrasi juga berhubungan dengan adanya penambahan beberapa fasilitas kesehatan di Kabupaten Kulon Progo, terutama rumah sakit (bertambah 1), poliklinik (bertambah 2), dan apotek (bertambah 14). Kota Yogyakarta memiliki indeks konsentrasi tertinggi $(10,76)$, nilai indeks konsentrasi fasilitas kesehatan yang dimiliki Kota Yogyakarta sangat kontras dengan kabupaten lainnya, terlebih dengan Kabupaten Gunungkidul $(0,51)$. Gap yang jauh antar wilayah ini terjadi karena Kabupaten Gunungkidul juga memiliki indeks sentralitas terendah. Kabupaten Gunungkidul merupakan kabupaten yang relatif kurang berkembang dengan kondisi topografi datar hanya sedikit sehingga kurang mendukung untuk dibangun fasilitas pelayanan wilayah. Perihal ruang wilayah tersebut dapat menjadi pembatas tempat tersebut secara fisik maupun nonfisik [33]. Selain itu, Kabupaten Gunungkidul memiliki kepadatan penduduk yang relatif rendah dibandingkan dengan kabupaten/kota lainnya di Provinsi DIY. Kondisi tersebut menyebabkan tidak terkonsentrasinya fungsi pelayanan dari fasilitas kesehatan di Kabupaten Gunungkidul dan menjadikannya terendah di antara kabupaten/kota lainnya.

Penentuan struktur ruang wilayah dalam rencana tata ruang wilayah (RTRW) juga mendasarkan pada fasilitas pelayanan yang tersedia di wilayah tersebut. Semakin baik performanya (jumlah, jenis, dan fungsinya) maka akan semakin tinggi hierarki pusat pelayanan atau sistem perkotaannya. Kota Yogyakarta dalam sistem perkotaan RTRW Provinsi DIY tahun 2019-2039 merupakan Pusat Kegiatan Nasional (PKN), yang berarti bahwa skala pelayanan Kota Yogyakarta sudah melayani kegiatan nasional atau beberapa provinsi [34]. Hasil dari analisis indeks konsentrasi fasilitas kesehatan pada tahun 2014 dan 2018 yang dilakukan peneliti menunjukkan kesesuaian dengan penetapan pusat pertumbuhan di Provinsi DIY. Meskipun demikian, penentuan suatu kabupaten/kota menjadi tempat pusat tidak cukup hanya melihat keberagaman fasilitas kesehatan yang ada, tetapi juga melihat daya layan fasilitas secara menyeluruh melalui tingkat ketersediaan dan persentase luas wilayahnya. Suatu tempat sentral yang merupakan salah satu tempat penting dan strategis yang berperan besar dalam pusat kegiatan maupun penyediaan fasilitas pelayanan untuk wilayahnya sendiri beserta wilayah di sekitarnya [7]. Tingkat konsentrasi fasilitas pelayanan menunjukkan pemusatan suatu fungsi sehingga menimbulkan daya tarik yang besar dan interaksi antar wilayah. Tingginya tingkat konsentrasi fasilitas pelayanan di suatu wilayah menjadi ciri pusat pertumbuhan dan perkembangan wilayah yang lebih besar dibandingkan wilayah lain. Salah satu pertimbangan suatu wilayah dijadikan pusat pertumbuhan yaitu karena adanya keuntungan aglomerasi yang berupa: kedekatan geografis, aktivitas sosial, ekonomi, maupun 
mobilitas penduduknya sehingga mampu memberikan daya tarik menuju wilayah dengan konsentrasi fasilitas pelayanan yang lebih tinggi.

\section{Kesimpulan}

Meningkatnya jumlah penduduk berbanding lurus dengan meningkatnya kebutuhan penduduk terhadap fasilitas pelayanan, tak terkecuali pada fasilitas pelayanan kesehatan. Urgensi peningkatan kuantitas dan kualitas fasilitas pelayanan kesehatan di suatu wilayah adalah untuk memenuhi kebutuhan penduduk dan meningkatkan kesejahteraan penduduk melalui fasilitas kesehatan yang memadai dan terjangkau. Ketersediaan fasilitas pelayanan kesehatan dasar dan rujukan di Provinsi DIY sudah sesuai dengan standar jumlah minimal yang ditetapkan dalam Peraturan Menteri PU No. 41/PRT/M/2007 dan SNI 03-1733-2004. Daya layan fasilitas kesehatan dasar di Provinsi DIY telah memenuhi kebutuhan ideal menurut jumlah penduduk yang dilayani dan jangkauan wilayah administrasi sesuai Peraturan Pemerintah RI No. 47 Tahun 2016. Akan tetapi sebaran fasilitas kesehatan rujukan atau tingkat lanjut di Provinsi DIY berupa rumah sakit belum terdistribusi secara merata, terutama di Kabupaten Sleman (masih mengelompok di 2 kecamatan) dan Kabupaten Gunungkidul (masih mengelompok di 4 kecamatan).

Ketersediaan fasilitas pelayanan yang ada di setiap wilayah di Provinsi DIY pada kurun waktu tertentu memberikan gambaran terhadap distribusi/sebaran fasilitas pelayanan dan perkembangan fasilitas pelayanan wilayah tersebut. Kecamatan yang memiliki fungsi pelayanan fasilitas kesehatan terbaik berada di Kecamatan Umbulharjo, Kota Yogyakarta. Hal ini menunjukkan adanya peran Kecamatan Umbulharjo dalam mengalokasikan wilayahnya untuk melayani wilayah sendiri dan wilayah sekitarnya. Tingginya konsentrasi fasilitas kesehatan di Kecamatan Umbulharjo juga mengindikasikan besarnya potensi wilayah untuk memegang peranan sebagai pusat pelayanan. Sementara fungsi pelayanan terendah berada di Kecamatan Purwosari, Kabupaten Gunungkidul. Dominasi Kota Yogyakarta sebagai pusat pelayanan wilayah di Provinsi DIY juga ditunjukkan oleh adanya konsentrasi fasilitas kesehatan yang tinggi. Indeks konsentrasi fasilitas kesehatan di Kota Yogyakarta (yaitu 10,90) memiliki selisih yang jauh dibandingkan dengan indeks konsentrasi kabupaten lain di Provinsi DIY. Hal ini memperkuat gejala primacy atau pemusatan perkembangan wilayah di Provinsi DIY yang masih terpusat Kota Yogyakarta dan Kawasan Perkotaan Yogyakarta.

Wilayah yang menjadi tempat pusat pelayanan kesehatan memiliki jumlah, jenis, dan skala pelayanan yang bervariasi, oleh karena itu perlu diimbangi dengan peningkatan fungsi dan akses pelayanan. Konsentrasi fasilitas kesehatan yang tinggi di suatu daerah perlu mempertimbangkan aksesibilitas yang baik sehingga jangkauan pelayanan kesehatan dapat merata dan dengan mudah diakses oleh masyarakat yang membutuhkan. Aspek tersebut sangat penting untuk menjadi pertimbangan perencana pembangunan agar tercipta kesejahteraan yang merata pada seluruh lapisan masyarakat, khususnya masyarakat Provinsi DIY. 


\section{Ucapan Terima Kasih}

Penelitian ini merupakan bagian dari Hibah Penelitian Fakultas Geografi UGM. Peneliti mengucapkan terima kasih atas bantuan dan dukungan yang diberikan oleh Program Studi Pembangunan Wilayah dan Fakultas Geografi UGM.

\section{Referensi}

[1] Sadali MI, Intizhar F, Aisyah. Analisis Ketersediaan Fasilitas Sosial di Kabupaten Banjarnegara, Sebagai Pendukung Kondisi Darurat Bencana dan Pengembangan Wilayah. Media Komun Geogr 2017;18:128-45. https://doi.org/10.23887/mkg.v18i2.12517.

[2] Kementerian Perencanaan Pembangunan Nasional/Bappenas. Rancangan Teknokratik Rencana Pembangunan Jangka Menengah Nasional 2020-201. 2019.

[3] Muta'ali L. Teknik Analisis Regional. Yogyakarta: Badan Penerbit Fakultas Geografi Universitas Gadjah Mada; 2015.

[4] World Health Organization. Refugee and Migrant Health 2018. https://www.who.int/migrants/en/ (accessed October 1, 2020).

[5] Republik Indonesia. UU No. 36 Tahun 2009 tentang Kesehatan. 2009.

[6] Peraturan Pemerintah Republik Indonesia Nomor 47 Tahun 2016 tentang Fasilitas Pelayanan Kesehatan.

[7] Muta'ali L, Widiyanto D, Sadali MI. Modul Praktikum Metode dan Teknik Analisis Sosial Ekonomi. Yogyakarta: Program Studi Pembangunan Wilayah Universitas Gadjah Mada; n.d.

[8] Aulia BU. Overview: Faktor Pendorong Terjadinya Keterkaitan Kota-Desa dari Segi Pergerakan Orang antara Kota Mojokerto dengan Wilayah Peri-Urban di Kabupaten Mojokerto. Desa-Kota 2020;2:58-69. https://doi.org/10.20961/desakota.v2i1.39267.58-69.

[9] Putri SW. Hari Kesehatan Nasional: Persebaran Fasilitas Kesehatan Indonesia Tidak Merata. AyobandungCom 2019. https://www.ayobandung.com/netizen/pr79668071/hari-kesehatan-nasional-persebaran-fasilitas-kesehatan-indonesia-tidakmerata?page=all (accessed January 10, 2022).

[10] Wahyudi MZ. Hampir 54 Persen Penduduk Indonesia Tinggal di Kota. KompasCom 2012. https://nasional.kompas.com/read/2012/08/23/21232065/ Hampir.54.Persen. Penduduk.Indonesia.Tinggal.di.Kota (accessed January 10, 2022).

[11] Kementerian Kesehatan RI. Profil Kesehatan Indonesia Tahun 2019. Jakarta: Kementerian Kesehatan RI; 2020.

[12] BPS Provinsi DIY. Tipologi Wilayah Hasil Pendataan Potensi Desa (PODES) 2014. 2015.

[13] Firmansyah RA, Hariyanto, Indrayati A. Dinamika Sistem Kota-Kota Dan Pemilihan Alternatif Pusat Pertumbuhan Baru di Kota Semarang. Geo Image 2016;5:46-51. https://doi.org/10.15294/geoimage.v5i2.13561.

[14] Utari MGES. Analisis Sistem Pusat Pelayanan Permukiman di Kota Yogyakarta Tahun 2014. Jejak J Econ Policy 2015;8. https://doi.org/10.15294/jejak.v8i1.3856.

[15] Dinas Kesehatan DIY. Profil Kesehatan D.I Yogyakarta Tahun 2018. 2019.

[16] Kementerian Kesehatan RI. Profil Kesehatan Indonesia 2018. Jakarta: Kementerian 
Kesehatan RI; 2019.

[17] BPS Kabupaten Bantul. Kabupaten Bantul dalam Angka 2015. 2015.

[18] BPS Kabupaten Gunungkidul. Kabupaten Gunungkidul Dalam Angka 2015. 2015.

[19] BPS Kota Yogyakarta. Kota Yogyakarta Dalam Angka 2015. 2015.

[20] BPS Kabupaten Kulon Progo. Kabupaten Kulon Progo Dalam Angka 2015. 2015.

[21] BPS Kabupaten Sleman. Kabupaten Sleman Dalam Angka 2015. 2015.

[22] BPS Kabupaten Bantul. Kabupaten Bantul dalam Angka 2020. 2020.

[23] BPS Kabupaten Gunungkidul. Kabupaten Gunungkidul Dalam Angka 2020. 2020.

[24] BPS Kota Yogyakarta. Kota Yogyakarta Dalam Angka 2020. 2020.

[25] BPS Kabupaten Kulon Progo. Kabupaten Kulon Progo Dalam Angka 2020. 2020.

[26] BPS Kabupaten Sleman. Kabupaten Sleman Dalam Angka 2020. 2020.

[27] Ritohardoyo S, Sadali I. Kesesuaian Keberadaan Rumah Tidak Layak Huni (RTLH) terhadap Tata Ruang Wilayah di Kota Yogyakarta. Tata Loka 2017;19:291-305. https://doi.org/10.14710/tataloka.19.4.291-305.

[28] Sari SMRP, Hardiana A, Putri RA. Efektivitas Perkotaan Gemolong Sebagai Pusat Pelayanan Permukiman di Kabupaten Sragen. Region 2017;12:83-92. https://doi.org/10.20961/region.v12i1.10172.

[29] Hardati P. Hierarki Pusat Pelayanan di Kecamatan Ungaran Barat dan Ungaran Timur Kabupaten Semarang. J Geogr Media Inf Pengemb Dan Profesi Kegeografian 2016;13:204-15. https://doi.org/10.15294/jg.v13i2.7977.

[30] Hariyani S, Usman F, Kurniawan EB. Strategy of Urban Settlement Planning Through a Model of Public Service Facilities. IOP Conf. Ser. Earth Environ. Sci., vol. 202, Surabaya: IOP Publishing Ltd; 2018. https://doi.org/10.1088/17551315/202/1/012011.

[31] Kurniawan A, Sadali MI. Keistimewaan Lingkungan Daerah Istimewa Yogyakarta. Yogyakarta: Gadjah Mada University Press; 2015.

[32] Arsandi AS, Wahyu R D, Ismiyati, Hernawan F. Dampak Pertumbuhan Penduduk Terhadap Infrastruktur di Kota Semarang. J Karya Tek Sipil 2017;6:1-14.

[33] Tickamyer AR. Space Matters ! Spatial Inequality in Future Sociology. Contemp Sociol 2000;29:805-13. https://doi.org/10.2307/2654088.

[34] Peraturan Daerah DIY Nomor 5 tahun 2019 tentang Rencana Tata Ruang Wilayah DIY Tahun 2019-2039. 